\title{
ANALISIS MOTIF BATIK MALUKU DALAM MEMBANGUN PENDIDIKAN MULTIKULTURAL
}

\author{
Iga Ayu Intan Candra \\ Fakultas Ilmu Tarbiyah dan Keguruan, IAIN Ambon \\ E-mail: iga.candrayu@gmail.com
}

\begin{abstract}
Abstrak
Batik Maluku merupakan perwujudan kebudayaan masyarakat Maluku melaui seni kriya tekstil. Penelitian ini mendeskripsikan dan menganalisis sejarah historis maupun filosofis dalam motif batik Maluku. Motif batik Maluku dianalisis atas dasar nilai-nilai beserta makna di dalamnya dan integrasinya dalam pendidikan multikultural. Motif dalam batik Maluku diantaranya adalah motif Pala Cengkeh, Kakehan, Tifa, Parang Salawaku dan Pattimura. Analisis terhadap motif batik Maluku dapat diaplikasikan dalam pembelajaran Seni Budaya pada materi Seni Rupa yaitu pembelajaran motif dan ragam hias. Tujuan pembelajaran Seni Budaya selaras dengan tujuan pendidikan multikultural karena seni adalah bagian dari budaya. Maka nilai-nilai yang mendukung terbangunnya pendidikan multikultural melalui batik Maluku adalah nilai kesadaran identitas diri, menghormati dan menghargai orang lain, menjunjung keberagaman dan menjaga solidaritas.
\end{abstract}

Kata Kunci: batik, Maluku, pendidikan, multikultural

\section{MOTIF ANALYSIS OF MOLUCCAN BATIK IN BUILDING MULTICULTURAL EDUCATION}

\begin{abstract}
Maluku Batik is a textile craft that embodies the Maluku people's culture. This study discusses and analyzes the historical and philosophical contexts in which Maluku batik themes originated. The themes are examined in terms of their inherent values and meanings and their integration into multicultural education. Clove Nutmeg, Kakehan, Tifa, Salawaku, and Pattimura are among the motifs. Analyses of Moluccan batik motifs can be used to teach art and culture through the study of Fine Arts materials, namely motifs and decorations. Studying arts and culture aims to advance intercultural education's goals, as art is a component of culture. Thus, the ideals underpinning the formation of intercultural education through Moluccan batik are self-awareness, respect for oneself and others, appreciation for diversity, and solidarity.
\end{abstract}

Keywords: batik, Moluccan, education, multicultural

\section{PENDAHULUAN}

Maluku merupakan wilayah kepulauan di Indonesia Timur yang memiliki etnis multikultural yang dihuni oleh berbagai etnis. Etnis Maluku Menurut Ajawaila (2005, p. 159) yakni, suku Bugis, suku Makassar, suku
Buton, suku Jawa, suku Sunda, suku Madura, Suku Minang, suku Batak, dan sebagainya. Selain itu juga terdapat berbagai suku dan sub suku di Maluku, yang dikenal sebagai masyarakat adat, seperti orang Ambon, orang Seram, orang Kei, orang Buru, orang Lease, 
dan lain-lain. Keadaan tersebut menyebabkan Maluku menjadi kepulauan multikultural yang sangat memungkinkan terjadinya asimilasi budaya. Asimilasi budaya yang terjadi di Maluku dapat kita ketahui berdasarkan hasil-hasil kebudayaan yang ada di Maluku. Hasil-hasil kebudayaan atau produk budaya dapat berupa benda seni, baik itu seni pertunjukan ataupun seni rupa. Seni rupa yang kita temui sebagai produk budaya diantaranya adalah seni gerabah, pahat/ukir dan tekstil. Karya seni tekstil yang banyak kita ketahui yakni seni batik yang memang telah menyebar diseluruh wilayah Indonesia.

Batik sebagai kearifan lokal khas Indonesia yang telah ditetapkan menjadi warisan dunia. Batik telah tersebar di seluruh Indonesia mengikuti motif-motif yang disesuaikan dengan kearifan lokal budaya setempat. Menurut Sutiyati (2016) Batik adalah sebuah kerajinan yang terbuat dari kain yang diberi hiasan berupa motif, warna, ornamen yang dibuat dengan cara di tulis atau di cap. Perkembangan batik di Indonesia adalah manifestasi kekayaan budaya daerah-daerah perbatikan seperti Solo, Yogyakarta, Pekalongan, Cirebon,Indramayu, Madura, Lasem, dan Sukoharjo. Batik tidak hanya terdapat di wilayah Pulau Jawa namun batik telah masuk ke wilayah Maluku.

Persebaran batik adalah melalui asimilasi telah menciptakan batik maluku dengan motif khasnya yang menggambarkan budaya masyarakat Maluku. Menurut Wakano (2019) sebagai kepulauan penghasil rempah atau spices island (pulau rempah-rempah), khususnya Cengkeh, Pala dan Pully. Bahwasanya sejak dahulu kala kepulauan Maluku telah menjadi tempat bertemunya berbagai etnis dari berbagai peradaban di dunia yang membangun jalinan Nusantara. Maluku juga menjadi pusat perdagangan dan politik dunia terutama bangsa Portugis, Spanyol, Inggris, Belanda, dan Jepang, selain Arab, China dan India. Tifa, Pala Cengkeh, Parang Salawaku dan Pattimura. Motif tersebut dapat menggambarkan bagaimana budaya mengekor melalui proses perdagangan. Alat musik Tutobuang dapat digambarkan sebagai bentuk bonang dalam gamelan jawa. Namun di maluku Tutobuang dimainkan dalam acara adat di Maluku. Dengan kata lain Batik maluku merangkum penggambaran budaya yang ada di Maluku melalui motif-motif yang dihadirkannya.

Batik sebagai produk seni mencerminkan nilai-nilai multikultural di dalamnya. Multikultural yang berasal dari kata multi dan kultur berarti jamak dan budaya. Sehingga istilah multikultural berarti keragaman dari berbagai budaya. Nilai multikultural dapat terwujud jika seseorang memahami kodratnya sebagai manusia yang diciptakan berbeda dari segala aspek. Sehingga batik sebagai produk budaya dapat menggambarkan nilai-nilai multikultural dari masyarakat lokal. yang memiliki keragaman budaya. Nilai-nilai multikultural dibangun dan diintegrasikan dalam pendidikan sehingga muncullah istilah pendidikan multikultural.

Pendidikan sebagai suatu proses penyampaian informasi kepada individu dari yang tidak tahu menjadi tahu. Menurut Nurkholis (2013) pendidikan lebih dari sekedar pengajaran, yang dapat dikatakan sebagai suatu proses transfer ilmu, transformasi nilai, dan pembentukan kepribadian dengan segala aspek yang dicakupnya. Dengan demikian pengajaran lebih berorientasi pada pembentukan spesialis atau bidang tertentu, oleh karena itu perhatian dan minat nya lebih bersifat teknis. Berdasarkan pemamparan tersebut dapat diketahui jika pendidikan tidak hanya membentuk kecerdasan melainkan membentuk sikap dan kepribadian seseorang menjadi lebih baik.

Sementara istilah multikulturalisme merujuk kepada kebudayaan. Koentjaraningrat $(2015$, p.2) merumuskan kebudayaan menjadi beberapa unsur yaitu bahasa, teknologi, 
sistem mata pencaharian hidup atau ekonomi, organisasi sosial, sistem pengetahuan, religi, dan kesenian. Sehingga multikultural adalah berbagai kebudayaan dan multikulturalisme sebagai suatu konteks mengacu pada ideologi atau paham terhadap penghargaan nilai-nilai budaya.

Andersen \& Cusher (1994, p.320) mengemukakan bahwa pendidikan multikultural adalah pendidikan mengenai keragaman kebudayaan. Definisi yang dikemukakan menyatakan adanya keberagaman kebudayaan sebagai objek studi yang dipelajari. Sehingga unsur kebudayaan harus masuk dalam penyusunan kurikulum dan dikembangkan di dalamnya. Berdasarkan pernyataan tersebut, pendidikan multikultural adalah penanaman nilai keragaman dari budaya melalui sistem pengajaran dan melalui kurikulum di lembaga pendidikan seperti sekolah maupun perguruan tinggi.

Batik maluku dengan motifnya yang bervariasi memberikan gambaran nilai-nilai masyarakat maluku baik itu dari mata pencaharian, komoditas, alat pertanian dan simbol-simbol tertentu sebagai ragam hias pada bangunan yang ada di Maluku. Penelitian ini dinilai sangat penting karena dengan penelitian ini akan diungkap sejarah historis maupun filosofis sehingga tercipta beberapa jenis motif batik yang ada di Maluku. Penelitian ini akan mencoba menganalisis nilai-nilai dalam motif batik maluku beserta makna di dalamnya dan integrasinya dalam pendidikan multikultural. Dengan memahami nilai-nilai multicultural yang terkandung dalam artefak budaya, peserta didik dapat mengenal jati diri bangsanya secara lebih bijak dan menjadi dasar untuk kemudian berkreativitas (Astuti, 2021).

Secara garis besar permasalahan yang diangkat dalam penelitian ini adalah, 1) Bagaimana analisis motif batik Maluku? dan 2) Bagaimana peran batik Maluku dalam membangun pendidikan multikultural di Maluku? Dari kedua permasalahan tersebut maka akan diperoleh pengertian motif batik maluku dikaji secara literatur dan peran motif batik maluku dalam membangun atau menumbuhkan pendidikan multikultural melalui nilai-nilai dibalik motif batik tersebut.

\section{METODE}

Metode penelitian ini merupakan penelitian deskriptif kualitatif dengan metode studi lapangan dan studi literatur. Penelitian deskriptif kualitatif dapat dikatakan sebagai penelitian yang menggambarkan kondisi objek penelitian secara sebenarnya dan menganalisisnya menggunakan teori yang relevan. Menurut Arikunto (2003, p.3) Penelitian deskriptif adalah penelitian yang dimaksudkan untuk menyelidiki keadaan, kondisi, atau halhal lain yang sudah disebutkan, yang hasilnya dipaparkan dalam bentuk laporan penelitian. Sementara studi lapangan dan studi literatur dilakukan observasi penggumpulan motif-motif batik yang ada di maluku dan membandingkannya dengan beberapa literatur berupa jurnal terkait kebudayaan Maluku.

Pendekatan kualitatif dipilih karena sangat sesuai dengan kajian yaitu analisis motif batik Maluku memerlukan data lapangan yang sesuai dengan keadaan masyarakat dan kebudayaan. Data dalam penelitian sebagai objek utama yaitu batik tidak dapat dipisahkan dari kondisi alamiahnya sebagai perwujudan atas motif-motif yang dihasilkan dan perannya dalam mengebangkan pendidikan multikutural.

Lokasi penelitian yaitu di beberapa toko souvenir di Kota Ambon yang menjual batik khas Maluku. Diantaranya adalah toko oleholeh The Ambon Manise Shop dan pengrajin Batik Thahirah Kebun Cengkeh Kota Ambon. Dipilihnya toko tersebut karena toko menjual produk batik dengan motif paling lengkap di Maluku.

Teknik pengumpulan data meliputi berupa studi lapangan meluputi observasi, wawancara dan dokumentasi. Menurut Sani 
(2017) Observasi dilakukan untuk mencari tahu tentang gambaran objek penelitian di lapangan. Sedangkan wawancara dan dokumentasi dilakukan untuk merekam dan menangkap kejadian serta fenomena yang terdapat dalam penelitian.

Teknik analisis data dalam penelitian ini yaitu teknik yang mengacu pada tiga tahapan, menurut Ian Dey dalam Moleong (2009:289) dari data yang diperoleh akan dianalisis dengan mempertimbangkan tiga proses yang berkaitan yaitu :

a. Mendeskripsikan fenomena, yaitu pemahaman dari mendeskripsikan fenomena adalah mendeskripsikan secara komprehensif dan teliti hasil penelitian yang diperoleh. Pendeskripsian dilakukan dengan memasukan informasi tentang intensitas suatu tindakan,makna suatu tindakan, mengorganisasikan tindakan, dan perkembangan yang terjadi dari waktu ke waktu.

b. Mengklasifikasikannya, yaitu Analisis data merupakan bagian integral dari pengklasifikasian data. Sebelum dianalisis data dipilah-pilah dan dipadukan kembali untuk menemukan konsep-konsep analisis.

c. Melihat bagaimana konsep-konsep yang muncul itu satu dengan yang lainnya berkaitan, yaitu Berdasarkan data yang diperoleh dari penelitian akan dihubungkan dengan teori yang sudah disusun peneliti berdasarkan konsep dari teori.

\section{HASIL DAN PEMBAHASAN Hasil}

Batik maluku merupakan produk tekstil Maluku yang telah termasuk kedalam oleholeh khas Maluku. Motif-motif batik di Maluku sangat bervariasi dan memiliki kecenderungan warna-warna berani seperti merah terang, biru dan putih. Selain itu batik Maluku mengangkat kebudayaan lokal Maluku sebagai motif batiknya seperti Tifa, Parang Sala- waku, Pala Cengkeh, Kakehan, dan Pattimura.

Menurut Susanto (1980, p.47) Motif batik memiliki pengertian yaitu ornamen dalam batik. Motif batik dapat dikatakan sebagai perpaduan garis, bentuk dan isen yang menghasilkan nilai estetis. Sebagaimana pendapat di atas Batik memiliki unsur-unsur yang menghasilkan nilai estetis. Unsur tersebut adalah harmonisasi atau perpaduan garis, bentuk dan isen. Garis merupakan tepian terluar batik bisa beruppa garis lurus maupun gelombang, sementara bentuk biasanya berupa benda, flora, fauna maupun benda lainnya. Sementara isen adalah motif penghias dalam bentuk yang menambah keindahan bentuk tertentu dalam motif batik.

Murtihardi, Mukminatun, \& Rugayah (1979, p.71) menjelaskan unsur-unsur yang membentuk ornamen motif batik yaitu : a. ornamen motif pokok atau utama; b. pelengkap atau isian motif; c. isen-isen motif. Berdasarkan pendapat tersebut terdapat unsur utama dan unsur pelengkap yang biasanya motif pokok merupakan motif yang menonjol dan memiliki nilai filosofis atau makna. Sementara isian adalah motif yang melengkapi batik sehingga muncul keharmonisan.

Pendapat lain terkaiat motif batik disampaikan oleh Riyanto (1992, p.11) Penggunaan motif batik dibagi menjadi 3 bentuk yakni stilisasi, distorsi, dan dekoratif. Stilisasi adalah penggayaan atau memperindah dengan meninggalkan ciri asalnya. Distorsi yaitu membuat perubahan bentuk untuk menonjolkan karakter. Sementara dekoratif adalah menyederhanakan bentuk tanpa mempertimbangkan unsur tiga dimensi dan biasanya mengarah pada hiasan.

Sebagaimana dari bentuk penggunaan motif batik diatas batik Maluku lebih cenderung menyederhanakan bentuk dan lebih mengarah kepada hiasan. Sebagaimana ditemui pada semua motif dalam batik Maluku 
kebanyakan menyederhanakan bentuk asli dari benda, tumbuhan dan manusia tidak ada unsur stilisasi maupun distorsi. Motif batik dapat digolongkan menjadi dua jenis yakni motif geometris dan motif semen. Motif semen Susunan ornamen motif semen ini terdiri dari tumbuh-tumbuhan, burung, binatang, sayap yang membentuk susunan yang harmonis.

Sebagai upaya membentuk karakteristik suatu daerah, masyarakat mulai mendeklarasikan keberadaan batik di daerahnya sebagaimana dengan adanya Batik Maluku. Observasi yang dilakukan peneliti pada toko-toko batik yang tersebar di kota Ambon terdapat motif-motif yang muncul dalam batik Malu$\mathrm{ku}$.

\section{Motif Pala Cengkeh}

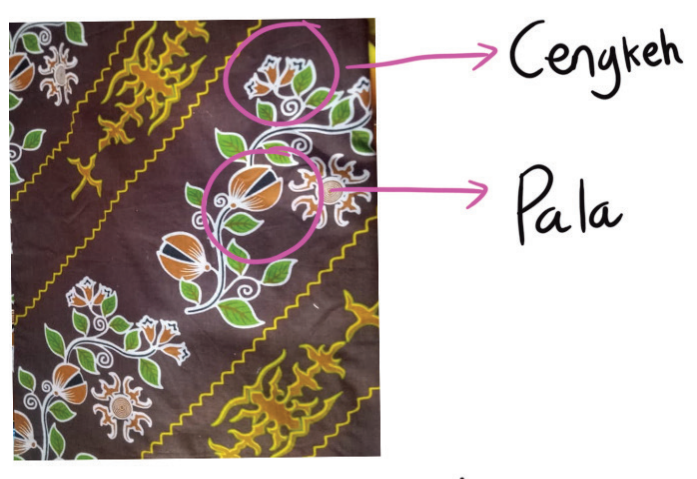

Gambar 1. Motif Pala Cengkeh dalam Batik Maluku Sumber : Dokumentasi Pribadi

Menurut Suroto (2010) Pala dan Cengkeh Merupakan komoditas utama perdagangan rempah di Maluku. Kedua tumbuhan ini adalah tumbuhan endemik yang hanya tumbuh di Maluku yaitu di kepulauan Ternate, Tidore, Halmahera dan kepulauan sekitar Maluku Utara. Sementara Pala merupakan tumbuhan yang berasal dari Pulau Banda. Pada Cengkeh menjadi sangat mahal karena cengkeh menjadi komoditas perdagangan dengan bangsa Eropa yang sangat mahal seba- gai pengawet makanan. Dari berbagai rempah yang diimpor, Cengkeh adalah rempah yang paling berharga.

Motif Pala Cengkeh lebih cenderung pada motif batik dekoratif dengan pola penyederhanaan bentuk buah Pala dan bunga Cengkeh tanpa memperhatikan unsur tiga dimensinya. Jenis motif mengarah pada jenis motif semen yaitu berupa tumbuhan. Secara visual motif pala dan cengkeh memberikan gambaran komoditasutama maluku hingga Maluku disebut sebagai jalur rempah Nusantara. Selain itu menunjukkan bahwa masyarakat Maluku dengan kontur wilayah kepulauan dan pegunungan memungkinkan masyarakat membudidayakan tanaman perkebunan seperti Pala dan Cengkeh. Dengan kata lain motif batik Pala dan Cengkeh adalah representasi mata pencaharian masyarakat Maluku sebagai komoditas perdagangan.

\section{Motif Kakehan}

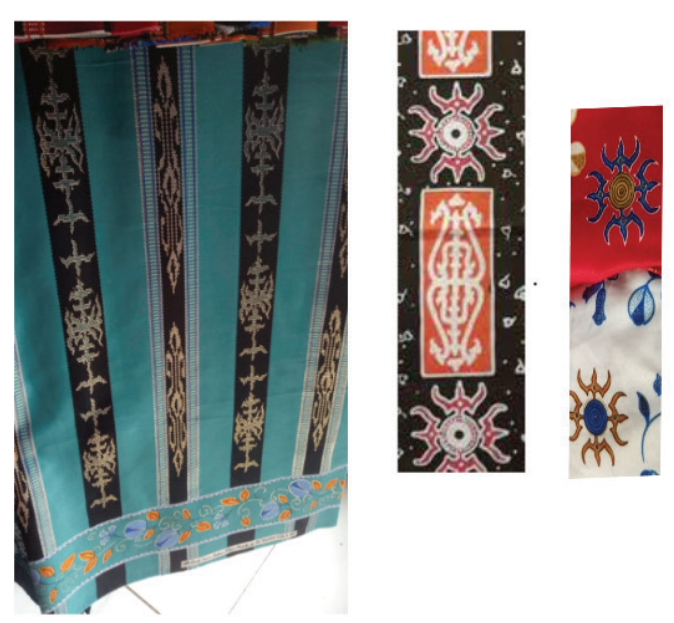

Gambar 2. Motif Kakehan Sumber : Dokumentasi Pribadi

Motif Kakehan merupakan ragam hias yang sering kita temui di Maluku. Motif Kahehan sering dijumpai pada objek-objek vital pemerintahan di Maluku, seperti pada tugu- 
tugu, gapura (gerbang), tembok taman kota (Lapangan Merdeka), salawaku (tameng), dan pada tiang-tiang Baileo (Rumah adat Maluku) dengan tujuan bahwa bangunanbangunan dengan hiasan Kakehan dapat memiliki keberanian dalam berperang. Kahehan merupakan jenis ragam hias yang berasal dari suku Alifuru di Pulau Seram. Kakehan merupakan simbol ornamen matahari yang di stilisasi.

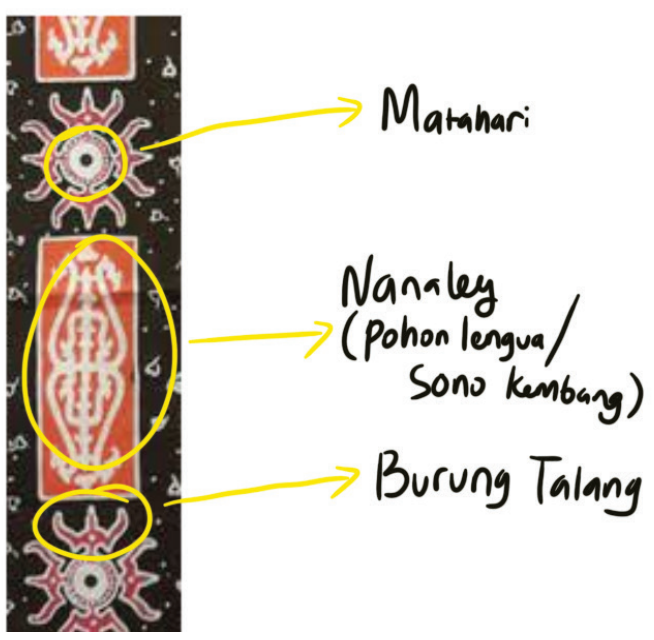

\section{Gambar 3. Simbol dalam Kakehan} Sumber : Dokumentasi Pribadi

Menurut Salenussa, Damayanti, dan Agustina (2010) melalui upacara Kakehan, tubuh pemuda pata siwa dihias pada dahi, lengan, dan dada. Bentuk dan unsur ornamen matahari dilambangkan sebagai simbol matahari yang di dalamnya memiliki makna simbolis keyakinan, pola pikir, norma, adat istiadat, dan tata nilai. Motif matahari yang digambarkan dalam batik tersebut berarti cahaya dan panas yang menunjukan kekuasaan dan berarti hubungan manusia dengan Tuhannya. Burung Talang menandakan adanya ikan di laut sehingga ornamen burung Talang berarti melimpahnya sumber daya laut bagi nelayan. Nanaley atau pohon Lingua atau disebut juga Sono Kembang adalah pohon yang kuat sebagai bahan bangunan maka simbol dari pohon ini diharapkan adanya keperkasaan dan kekuatan.

\section{Motif Pattimura}

Dalam motif Pattimura adalah batik yang kompleks karena memasukkan semua unsur Maluku didalamnya. Terdapat beberapa gambar yang mendominasi batik yakni, gambar Patung Pattimura, Perahu, Tifa, Parang Salawaku dan Ornamen Kakehan.

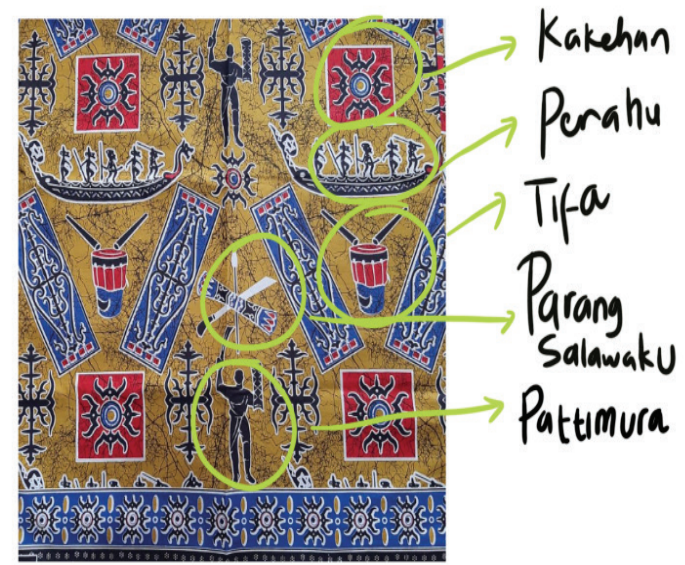

Gambar 4. Motif Pattimura

Sumber : Dokumentasi Ambonmaniseshop

Kakehan sepertihalnya diungkapkan di bagian motif Kakehan merupakan lambang filosofis dari keberanian dan semangat masyarakat Maluku. Simbol perahu menunjukkan bahwa Maluku adalah wilayah kepulauan dengan mata pencaharian masyarakat Maluku. Perlu diketahui juga jika masyarakat Maluku merupakan masyarakat yang menjadikan ikan laut sebagai sumber protein utama dibandingkan dengan sumber protein lain seperti telur, dan daging.

Tifa merupakan alat musik khas maluku yang menyerupai kendang dengan menggunakan kulit rusa sebagai membrannya. Tifa merupakan alat musik khas Maluku yang cara memainkannya dengan cara dipukul dengan menggunakan gaba-gaba yaitu pelepah 
sagu yang dipotong dan dikeringkan. Tifa biasanya dimainkan dalam pertunjukan Tifa Tutobuang, mengiringi tarian perang, Tari Lenso (Tari Pergaulan Maluku).

Parang Salawaku merupakan senjata tradisional dari Maluku yang terdiri dari parang dan salawaku (perisai). Parang salawaku merupakan simbol dari kemerdekaan rakyat Maluku. Senjata ini pada jaman dahulu digunakan sebagai alat untuk berperang melawan penjajah. Parang Salawaku juga digunakan sebagai property dalam tarian Cakalele yang merupakan tarian perang yang ditarikan oleh pemuda-pemuda.

Menurut Huliselan (2017) Pattimura adalah pahlawan Maluku, dikisahkan Thomas Matulessy Kapitan Pattimura sebagai "seorang laki-laki kabaressi" adalah pejuang yang gagah berani karena itu perlu diteladani. Sedangkan di pihak lain syair "Belanda lia dia sama Tuan yang mulia" mengandung makna: meremehkan dan merendahkan Penjajah Belanda atau dengan kata lain Belanda bukanlah orang yang perlu diagungkan atau ditakuti dan tidak memiliki status sosial yang lebih tinggi dari Orang Maluku. Semua manusia adalah sama. Syair ini menjelaskan juga bahwa perjuangan Thomas Matulessy melalui Perang Pattimura telah mampu mengembalikan harga diri, martabat dan identitas Orang Maluku. Berdasarkan beberapa motif yang dihadirkan dalam Batik motif Pattimura menggunakan teknik stilisasi atau diperindah dari bentuk aslinya dengan lebih menyederhanakan bentuk dan tidak memperhatikan aspek tiga dimensi.

\section{Pembahasan}

Motif batik Maluku adalah representasi persatuan di Maluku yang terdiri dari berbagai etnis dan Budaya. Dikatakan demikian karena batik Maluku menampilkan visualisasi kebudayaan maluku dalam satu produk. Keberagaman yang ada di masyarakat seperti perbedaan suku, ras, budaya dan agama ada- lah kondisi masyarakat yang dapat dikatakan sebagai kondisi masyarakat multikultural.

Menurut Pratjichno (2010) Pendidikan seni mampu menjadi media alternatif mewujudkan pendidikan multikultural melalui kegiatan apresiasi, kreasi, penikmatan, dan pengkajian nilai-nilai sebuah karya seni. Sebab dalam konsep pendidikan seni memuat wacana pendidikan plural dan multikultural, seperti untuk menanamkan suatu pemahaman, penghargaan dan penilaian atas budaya seseorang, serta menanamkan sebuah penghormatan dan keingintahuan tentang budaya etnis orang lain kepada peserta didik.

Siswa sekolah penting mengenal ragam hias Maluku sebagaimana dalam silabus kelas VII mata pelajaran Seni Budaya untuk Kompetensi Dasar (KD) yang harus dicapai peserta didik diantaranya:

\subsection{Memahami konsep dan prosedur} menggambar gubahan flora dan fauna serta geometrik menjadi ragam hias

4.2. Menggambar gubahan flora dan fauna serta geometrik menjadi ragam hias

Jika dihubungkan dengan SK dan KD Seni Rupa yang ada pada mata pelajaran Seni Budaya Sub. Seni Rupa maka penting belajar ornamen-ornamen yang ada di daerah masing-masing sebagai pembelajaran berbasis budaya lokal. Batik Maluku sangatlah tepat untuk mengenalkan stilisasi dari tumbuhan yang menjadi ikon Maluku yaitu buah Pala dan Cengkeh. Sementara ragam hias Maluku yang ada pada batik yaitu simbol Kakehan yang merupakan simbol-simbol suci dari masyarakat Alifuru di Pulau Seram. Selain belajar ragam hias maka peserta didik juga akan memaknai simbol-simbol tersebut sebagai simbol yang melambangkan nilai ketuhanan, kebesaran alam, keberanian dan kemakmuran.

Tujuan pendidikan seni rupa di sekolah Menurut Salam (2003) diantaranya adalah, 1) mengembangkan keterampilan menggambar, 
2) menanamkan kesadaran budaya lokal, 3) mengembangkan kemampuan apresiasi seni rupa, 4) Menyediakan kesempatan mengaktualisasikan diri, 5) meningkatkan kemampuan bidang seni rupa, 6) mempromosikan gagasan multikultural. Pada poin ke enam ditekankan bahwa mempromosikan gagasan multikultural adalah tujuan dari pendidikan seni rupa. Seni rupa mempelajari batik sebagai salah satu bahan kajian yang cukup sering dikaji. Sehingga kajian-kajian batik akan menambah kecintaan peserta didik pada bangsanya. Dengan menggunakan batik maka akan menunjukkan semangat keindonesiaan satu bangsa dan negara yang berbeda tetapi tetap satu. Selain itu peserta didik yang berkarya seni batik akan melakukan napak tilas dari kebudayaan dengan bersentuhan langsung pada kain, malam dan canting sebagai alat membatik.

Setelah mendalami pentingnya batik dalam pendidikan multikultural dan integrasinya dalam mata pelajaran dan batik maka nilai-nilai multikultural yang dapat dibangun dari mempelajari motif batik Maluku diantaranya adalah :

\section{Kesadaran Identitas Diri}

Kesadaran identitas adalah pemahaman terhadap jati diri atau asal usulnya sebagai bagian dari masyarakat tertentu. Kesadaran jati diri jika dihubungkan dengan pemahaman motif batik Maluku dalam memaknai pendidikan multikultural adalah proses apresiasi dan pemaknaan. Pada saat mengapresiasi, seorang peserta didik akan menemukan bahwa motif yang dihadirkan dalam batik Malu$\mathrm{ku}$ adalah tumbuhan, benda, ornamen, alat musik dan pahlawan dari tanah Maluku. Dengan proses pengamatan terhadap motif-motif tersebut maka akan muncul rasa kesadaran jati diri sebagai orang Maluku dengan segala kebudayaan di dalamnya.

Motif-motif batik memang sengaja mengambil benda, flora, maupun fauna dari daerah batik itu berasal. Tujuan batik dibuat demikian adalah untuk menonjolkan nilai-nilai budaya yang menjadi ciri khas dari suatu daerah. Seseorang akan menginternalisasi nilai multikultural jika dia mengetahui dan memahami jati dirinya dari proses mengenal budaya. Motif buah Pala, Cengkeh, Tifa, Kakehan, Parang Salawaku, Pattimura merupakan akar budaya Maluku dan simbol jati diri.

2. Menghormati dan Menghargai Orang Lain Seni yang halus, indah dan menggugah perasaan penikmatnya akan memunculkan kepekaan perasaan dan rasa menghargai orang lain. Menghargai orang lain dalam artian menjaga sikap sopan santun terhadap sesama dengan tidak membeda-bedakan. Menghargai dapat berupa rasa hormat pada pilihan dan keberagaman yang dimiliki setiap orang.

Mempelajari motif batik Maluku akan menumbuhkan rasa menghormati dan menghargai sesama, karena walaupun berbeda secara ras dan agama tetapi kita berada di tanah yang sama yaitu Maluku. Sebagaimana adanya nilai kesadaran jati diri maka akan muncul nilai-nilai toleransi antar sesama. Pengamatan motif batik mengajarkan kita agar menjaga budaya atau persatuan melalui sikap toleransi dengan menghargai dan menghormati orang lain.

\section{Menjunjung Keberagaman}

Keberagaman adalah esensi dari masyarakat multikultural. Masyarakat multikultural menjadi rawan konflik karena perbedaan yang mendasari terbentuknya masyarakat tersebut. Indonesia sebagai negara multikultural hendaknya dapat menjunjung keberagaman sebagai kebanggaan. Keberagaman dapat menumbuhkan kebanggaan karena penghargaan dan kebanggan atas hasil kebudayaan yang beragam dan estetik. Indonesia disebut dengan Bhineka Tunggal Ika karena kita hidup dalam kebhinekaan yang berbeda-beda tetapi tetap satu Bangas Indonesia. 
Melalui apresiasi batik Maluku baik berupa pengamatan maupun penggunaan batik dalam kehidupan sehari-hari akan menumbuhkan kebanggan terhadap keberagaman. Karena dari batik Maluku kita belajar bahwa kita memiliki budaya lokal yang patut dijunjung dan setara dengan budaya lainnya. Dalam perbedaan budaya kita menghargai dan menjunjung keberagaman tersebut sebagai suatu yang berharga untuk dijaga dan dihormati satu sama lain.

\section{Menjaga Solidaritas}

Solidaritas adalah saling mempercayai satu sama lain dalam kebersamaan yaitu merasa senasib. Nilai solidaritas sangat penting agar masyarakat tidak mudah terbawa budaya asing dan terpecah belah karena datangnya suatu isu tertentu. Sebagai bangsa yang kuat haruslah memiliki rasa solidaritas yang tinggi.

Pemahaman terhadap motif batik Maluku menunjukkan nilai solidaritas sebagai orang Maluku. Nilai dalam motif Kakehan menunjukkan semangat dan kemenangan dalam perang yang artinya dalam motif tersebut terdapat nilai senasib seperjuangan atau solidaritas. Maka motif Kakehan dapat kita temui di setiap sudut kota Ambon sebagai representasi agar selalu menumbuhkan semangat dan mengingat bahwa masyarakat Maluku pernah berjuang bersama melawan penjajah.

\section{PENUTUP}

Batik Maluku merupakan gambarabn nilai-nilai masyarakat Maluku, yaitu dari mata pencaharian, komoditas, alat pertanian dan simbol-simbol. Batik Maluku diciptakan berdasarkann budaya Lokal Maluku dan sangat dekat dengan masyarakat Maluku. Batik yang asalnya dari Jawa telah diadaptasi dengan mengedepankan motif-motif asli maluku.

Penelitian ini mengungkap sejarah historis maupun filosofis sehingga tercipta beberapa jenis motif batik yang ada di Maluku. Penelitian ini akan mencoba mengana- lisis nilai-nilai dalam motif batik maluku beserta makna di dalamnya dan integrasinya dalam pendidikan multikultural. Batik Maluku memiliki motif-motif khas yaitu motif Pala Cengkeh, Kakehan, Tifa, Parang Salawaku dan Pattimura. Pala Cengkeh adalah hasil bumi asli Maluku yang pernah sangat diperebutkan di masa penjajahan Portugis. Tifa sebagai alat musik asli Malu$\mathrm{ku}$ yang mengiringi berbagai pertunjukan tari dan musik. Sementara Parang Salawaku adalah senjata asli Maluku beserta Salawaku (perisai) yang menggambarkan semangat berperang bagi masyarakat Maluku. Analisis motif batik maluku dapat diaplikasikan dalam pembelajaran Seni Budaya pada materi Seni Rupa yaitu pembelajaran motif dan ragam hias. Tujuan pembelajaran Seni Budaya selaras dengan tujuan pendidikan multikultural karena seni adalah bagian dari budaya.

Pendidikan multikutural adalah adanya penerimaan atas perbedaan yang ada pada masyarakat multikutur. Kesadaran seni akan membawa masyarakat memahami keberagaman dan pentingnya menjunjung kebudayaan untuk persatuan. Batik Maluku dengan motif-motif khasnya adalah cerminan persatuan masyarakat Maluku yang turut membangun pendidikan Multikultural. Nilai-nilai dari motif batik Maluku adalah wujud dari nilai pendidikan multikultural. Nilai multikultural dari motif batik Maluku adalah nilai kesadaran identitas diri, menghormati dan menghargai orang lain, menjunjung keberagaman dan menjaga solidaritas.

\section{DAFTAR PUSTAKA}

Ajawaila, J. W. 2005. Dinamika Budaya Orang Maluku dalam Maluku Menyambut Masa Depan. Ambon: Lembaga Kebudayaan Daerah Maluku.

Andersen, \& Cusher. 1994. Multicultural and Interultural Studies. Sydney: Prentice-Hall. 
Arikunto, S. 2003. Prosedur Penelitian (Suatu Pendekatan Praktek). Jakarta: PT Asdi Mahasatya.

Astuti, E. P., Suardana, I. W., Ambarwati, D. R. S., Wulandari, D., \& Isa, B. (2021). Teachers' Perceptions of Museum-Based Learning and Its Effects on Creativity: A Preliminary Study. Proceedings of the 4th International Conference on Arts and Arts Education (ICAAE 2020), 552(ICAAE 2020), 215-221. https:// doi.org/10.2991/assehr.k.210602.043

Koentjaraningrat. 2015. Kebudayaan Mentalitas dan Pembangunan. Jakarta: PT Gramedia Pustaka Utama.

Moleong,Lexy.J.2009.Metodologi Penelitian Kualitatif. Bandung : PT.Remaja Rosdakarya.

Murtihardi, Mukminatun, \& Rugayah, S. 1979. Pengetahuan Teknologi Batik (1 ed.). Jakarta: Direktorat Pendidikan Menengah Kejuruan.

Nurkholis, N. 2013. Pendidikan dalam Upaya Memajukan Teknologi. Jurnal Kependidikan, 1(1), 24-44. https://doi. org/10.24090/jk.v1i1.530

Pratjichno, B. 2010. Pendidikan Seni Sebagai Alternatif Pendidikan Multikultural. Journal of Arts Research and Education, 10(1).https://doi.org/https://doi. org/10.15294/harmonia.v10i1.54
Riyanto, D. 1992. Proses Batik. Solo: CV Aneka.

Salenussa, I. E., Damayanti, M. P., \& Agustina, L. 2010. Aplikasi Motif Tato Kakehan pada Media Batik sebagai Upaya Pelestarian. Malang.

Sani, M.Budi Zakia. 2017. Kesenian Madihin Di Banjarmasin Kalimantan Selatan Dalam Tinjauan Aksiologi Dan Relevansinya Terhadap Pendidikan Karakter. Jurnal Imaji. 15 (1). 1-17. https://doi. org/10.21831/imaji.v15i1

Suroto, H. 2010. Masa Surut Perdagangan Rempah-Rempah Maluku. Jurnal Kepala Arkeologi, 6(11), 110-116. https:// doi.org/10.24832/kapata.v6i11.148

Sutiyati,Endang. 2016. Nilai Filosofi Motif Parang Rusak Gurdo Dalam Tari Bedhaya Harjuna Wiwaha. Jurnal Imaji, 14 (1), 1-15. https://doi.org/10.21831/imaji.v14i1.9530

Susanto, S. (980. Seni Kerajinan-Kerajinan Batik Indonesia. Yogyakarta: Balai Penelitian Batik dan Kerajinan.

Wakano, A. (2019). Nilai-nilai Pendidikan Multikultural dalam Kearifan Lokal Masyarakat Maluku. Al-Iltizam: Jurnal Pendidikan Agama Islam, 4(2), 26-33. https://doi.org/10.33477/alt.v4i2.1006 